\title{
STUDENTS' PROBLEMS IN LEARNING ENGLISH USING SCIENTIFIC APPROACH: A STUDY AT SENIOR HIGH SCHOOLS 1 MATARAM
}

\author{
Panji Guruh Indiartho ${ }^{1 *}$, Sahuddin ${ }^{2}$, Lalu Ali Wardana ${ }^{3}$ \\ Universitas Mataram \\ *email:panji.guruh@gmail.com
}

\begin{abstract}
This study aimed at investigating problems encountered by students in This study aimed to investigating problems encountered by students in learning English using scientific approach. This study also tried to found out factors that may causes the problems. This study is of quantitative descriptive research. There were 23 English students from Senior High School 1 Mataram selected as the participants of this research. The data were collected by means of questionnaire, interview, and observation. The data from questionnaire and interview were analyzed using thematic analysis. The observation used to collect the necessary data in classroom situation and strengthen questionnaire data. The problems investigated were in five points; (1) problems in observing stage (2) problems in questioning stage (3) problems in collecting data stage (4) problems in associating stage and (5) problems in communicating stage. The results of this study showed that the problems in observing stage are: a) students are not active in developing meaning and understanding particular concept, law or principles; b) students are unable to identify problems or learning objective. Problems in questioning stage are: a) students cannot develop their creativity, curiosity; b) the students fail to form questions to build critical thinking. Problems in collecting data stage are: a) students fail to develop their politeness, respect others opinion; b) students fail to develop the ability to communicate. Problems in associating stage is: a) students are unable to think inductively or deductively in concluding the material being studied. In communicating stage no problems were found. The other result shows that there are 5 factors that may cause the problems. The factors causing the problems are: a) students' motivation; b) students' characteristics; c) self-confidence of students; d) teacher; e) friends. Based on the results of the study, it is suggested to English teachers, students, government and all practitioners to take this as considerations in improving education in Indonesia through the effective implementation of scientific approach.
\end{abstract}

Keywords: Problems, English Students, Scientific approach

\section{INTRODUCTION}

In Indonesia's curriculum, English becomes a compulsory subject with a very important existence. The curriculum in Indonesia has changed at least eleven times. As it is known, the latest curriculum is curriculum 2013. In the regulation issued by the Minister of Education and Culture (Permendikbud) No. 81a/2013, it is stated that the learning process according to the curriculum 2013 is a process of education which provide opportunities for students to be more active and to gain knowledge, skill, and attitude independently.

Therefore, Scientific Approach is implemented in curriculum 2013 that fulfill the demand of its principles.
Scientific Approach is a new approach in English Language Teaching because the term "scientific" is more familiar with natural science, social science and management. Abidin (2014) states that "there are five steps of learning activity that must be conducted in learning process: (1) observing; (2) questioning; (3) collecting data; (4) associating; (5) communicating".

The implementation of scientific approach often meets obstacles. According to Trisagita (2018), difficulties in implementation are mostly to the classroom management in which students are the sources of the problems. It is found that teacher is hard to motivate the students to be active in the class and the 
proficiency of students is not appropriate with the scientific approach. Thus, that makes process of learning does not run well.

This study analyzed the students' problems in learning English by using scientific approach. Specifically, the steps of scientific approach: observing, questioning, collecting data, associating, and communicating. This study focused on analyzing the problems of $10^{\text {th }}$ grade of SMAN 1 Mataram faced in learning steps in scientific approach.

Furthermore, two research questions are proposed in the study they are: a) what are the problems encountered by students of $10^{\text {th }}$ grade of Senior High School 1Mataram in learning English using scientific approach? (b) what are factors causing the problems in learning English using scientific approach faced by students of $10^{\text {th }}$ grade of Senior High School 1 Mataram? The objectives of this study are to find out: (a) kinds of problems encountered by students of $10^{\text {th }}$ grade of SMAN 1 Mataram in learning English using scientific approach, (b) factors causing the problems in learning English using scientific approach faced by students $10^{\text {th }}$ grade of Senior High School 1 Mataram.

\section{LITERATURE REVIEW}

\section{A. Scientific Approach}

Daryanto (2013) states that the teaching and learning using scientific approach is a process of teaching and learning which formulated in order to the students can active in constructs the concepts and principles of the material through the steps of observing (to identify or to solve the problem), formulates the problem, pose or formulates a hypothesis, gathering the data with various techniques, analyze the data, gives conclusion and communicate the concepts and principles which was found.

\section{B. Principles of Scientific Approach}

According to Directorate General of Junior High School Management, 2014, in Sarwanti, (2016), learning by implementing scientific method is based on the following principles: 1) Be studentcentered i.e. the students physically and mentally take an active participation in developing meaning and understanding particular concept, law or principles; 2) Develop students' self-concept i.e developing particular concept based on their own understanding; 3) Avoid verbalism; 4) Give opportunity to students to assimilate and accommodate concepts, law, and principles; 5) Force the development of students' thinking capability; 6) Develop students' learning motivation; 7) Force opportunity for students to train their ability in communication; 8) Likely build validation process towards concepts, laws, and principles which are deconstructed by students in terms of its cognitive structure; 9) Involve scientific process skill in constructing concepts, laws, and principles; 10) Involve potentially cognitive process in stimulating intellectual development especially high order thinking. The results of learning by implementing scientific method are in the forms of concepts, laws, or principles which are deconstructed by students with the teacher's help. In a specific condition, the data needed to answer the questions are not likely collected directly by students since the data are sometimes got in a long time.

\section{The Steps of Scientific Approach in Learning English}

Based on Sarwanti, (2016) these are steps of scientific approach in learning English:

\section{1) Observing}

In the language learning process, observing means reading and/or listening to texts. Students are exposed to models of text in order to list items they need to 
know in order to understand and/or produce texts or communicate ideas. The texts can be authentic and/or simplified. The items to list basically include the social function of the text, text structure, grammar, and vocabulary. Some activities conducted in this stage are for example, students listen to an audio recording, watch a video, watch the teacher (with or without other students) demonstrate a monologue or dialogue, watch other students act out a monologue or dialogue, and read texts.

\section{2) Questioning}

In this second step students ask or formulate questions based on the identified items. The questions at least cover all of the achievement indicators stated in the lesson plan. In this step of learning, students are encouraged to propose temporary answers based on their knowledge and/or limited information they have.

\section{3) Collecting data/information (experimenting)}

In experimenting, students collect data/information to answer the questions formulated in the second step. They use one or more techniques such as observation (e.g., watching videos or listening to audio recording), interviewing resource persons, and reading books. The activities in this stage are for example watching more videos, listening to more audio recordings, listening to more sample expressions, reading more texts, looking up words into the dictionary, interviewing resource people, reading books on grammar, pronunciation, vocabulary, etc, assigned by the teacher, accessing website links, doing exercises, or practicing the grammar, vocabulary, or pronunciation.

\section{4) Associating (analyzing data/information)}

In this step, students analyze data/information to answer their questions and draw conclusions. With or without teacher's support students sort out, classify, and identify patterns to answer their questions. Some activities can be alternatives, for instance identifying patterns (grammar, vocabulary, or pronunciation), formulating patterns (grammar, vocabulary, or pronunciation), finding answers for the formulated questions, or drawing conclusions. To facilitate the students in analyzing data/information the teachers should help students see patterns to answer questions, and also help them draw conclusions.

\section{5) Communicating}

\section{(answers/conclusions)}

In the communicating step students communicate their answers or conclusions to the class in writing and/or orally. Their answers (conclusions) represent a new knowledge they 'construct' or learn. At the end of this step the students are expected to have learned the necessary knowledge (especially about the social function of the text, structure of the text, grammar, and vocabulary) in order to comprehend and create texts. In this step, students present their answers (conclusions) to the class, to the other groups, display their answers (conclusions) or exchange their findings (answers/conclusions) to the other groups. In this step teachers should play some roles, for example providing feedback - correction, and enriching the knowledge that the students 'construct'.

\section{Factors that Influence Learning Process}

According to Aunurrahman (2014) there are internal factors that influence in learning process includes: 1) Characteristics of Students; 2) Attitudes;
3) Motivation;
4) Concentration; 
Processing Learning Materials; 6) Exploring Learning Outcomes; 7) Confidence; 8) Study Habit. Besides internal factors, there are teacher, social environment, curriculum, and facilities asexternal factors that influence learning.

\section{RESEARCH METHODS}

This study employs quantitative descriptive research. There were 23 English students from Senior High School 1 Mataram selected as the participants of this research. The teacher has applied curriculum 2013 and have already implemented scientific approach in classroom.

The data were collected by means of observation, questionnaire and interview. The data from questionnaire and interview were analyzed using thematic analysis. The observation used to collect the necessary data in classroom situation and strengthen questionnaire data. The problems investigated were in five points;
(1) problems in observing stage (2) problems in questioning stage problems in collecting data stage (4) problems in associating stage and (5) problems in communicating stage.

\section{FINDINGS AND DISCUSSION}

\section{A. The Problems Encountered by Students \\ The Problems in Observing Stage}

From the result of observations, and questionnaires, it was found that only one item seen as a problem. That is read the text or material being studied. The data show that students do not read the text or material being studied. It was a problem because Students is not active, while one of the principles of Scientific Approach is the Students physically and mentally take an active participation in developing meaning and understanding particular concept, law or principles. But in fact students do not take that opportunity.

Table 1. Observation sheet (Observing stage)

\begin{tabular}{lcc}
\hline \multicolumn{1}{c}{ STATEMENT } & YES & NO \\
\hline 1. Read the text or material being studied & & V \\
\hline 2. Listen and watch the presentation carefully (audio,video,monollog, or dialog) & V & \\
\hline 3. Note the importatnt part & V \\
\hline
\end{tabular}

Table 2. Questionnaire Percentages (Observing stage)

\begin{tabular}{lcc}
\hline \multicolumn{1}{c}{ STATEMENT } & PERCENTAGES & CATEGORIES \\
\hline 1. Read the text or material being studied & $77,3 \%$ & HIGH \\
\hline $\begin{array}{l}\text { 2. Listen and watch the presentation carefully } \\
\text { (audio,video,monollog, or dialog) }\end{array}$ & $81,8 \%$ & VERY HIGH \\
3. Note the importatnt part & $79,1 \%$ & HIGH \\
\hline
\end{tabular}

\section{The Problems in Questioning Stage}

The questioning activity trains Students to develop creativity, curiosity, and the ability to form questions to build critical thinking. In this stage, it was found that three items seen as problems that are: 1) ask the social function of the text; 2) ask structure of the text; 3) ask the linguistics elements of the text. That three items are in low categories; it means that most of
Students do not do the activities. The Students do not do that three activities based on observations sheet Social function, structure, and elements of the text are the learning objectives in material that they are learn. There are problems because Students cannot develop their creativity, curiosity, and the ability to form questions to build critical thinking in this stage. 
Table 3. Observation sheet (Questioning stage)

\begin{tabular}{lll}
\hline \multicolumn{1}{c}{ STATEMENT } & YES & $\mathrm{NO}$ \\
\hline 1. Formulate questions & $\mathrm{V}$ \\
\hline 2. Do a question and answer with the teacher & $\mathrm{V}$ & \\
\hline 3. Ask the social function of the text & $\mathrm{V}$ \\
\hline 4. Ask structure of the text & $\mathrm{V}$ \\
\hline 5. Ask the linguistics elements of the text & $\mathrm{V}$ \\
\hline
\end{tabular}

Table 4. Questionnaire Percentages (Questioning stage)

\begin{tabular}{lcc}
\hline \multicolumn{1}{c}{ STATEMENT } & PERCENTAGES & CATEGORIES \\
\hline 1. Formulate questions & $62,7 \%$ & HIGH \\
\hline 2. Do a question and answer with the teacher & $69,1 \%$ & HIGH \\
\hline 3. Ask the social function of the text & $39,1 \%$ & LOW \\
\hline 4. Ask structure of the text & $38,2 \%$ & LOW \\
\hline 5. Ask the linguistics elements of the text & $39,1 \%$ & LOW \\
\hline
\end{tabular}

\section{The Problems in Collecting Data Stage}

According to Permendikbud No. 81a Th.2013, collecting data trains students to develop a conscientizes, honesty, politeness, respect others' opinions, the ability to communicate, and develop learning habits. Based on the results of the questionnaire, the lowest percentages are interviews with others (parent, friend, senior, or etc.) that is
$38.2 \%$ and interview with the teacher that is $39.1 \%$. They can get more information about the material being studied from interview activity, but most of them do not do it. Most of students not doing interviews, whether interview with the teacher or interviews others (parent, friend, senior, or etc) and it was problems because students failed develop their ability of communicate.

Table 5. Observation sheet (Collecting Data stage)

\begin{tabular}{lcc}
\hline STATEMENT & YES & NO \\
\hline 1. Looking for more information from internet & $\mathrm{V}$ & \\
\hline 2. Read the text or material being studied from another resources & V \\
\hline 3. Listen and watch the presentation from another resources & $\mathrm{V}$ \\
\hline 4. Interview with the teacher & $\mathrm{V}$ \\
\hline 5. Interviews with other besides teacher (friend, parent, senior, etc) & $\mathrm{V}$ \\
\hline 6. Open the dictionary & $\mathrm{V}$ \\
\hline 7. Do Excercises & $\mathrm{V}$ \\
\hline 8. Practice grammar, vocabulary, dan pronunciation & $\mathrm{V}$ \\
\hline
\end{tabular}

Table 6. Questionnaire Percentages (Collecting Data stage)

\begin{tabular}{lcc}
\hline \multicolumn{1}{c}{ STATEMENT } & PERCENTAGES & CATEGORIES \\
\hline $\begin{array}{l}\text { 1. Looking for more information from internet } \\
\text { 2. Read the text or material being studied from another } \\
\text { resources }\end{array}$ & $81,8 \%$ & VERY HIGH \\
\hline 3. Listen and watch the presentation from another resources & $78,2 \%$ & HIGH \\
\hline 4. Interview with the teacher & $72,7 \%$ & HIGH \\
\hline $\begin{array}{l}\text { 5. Interviews with other besides teacher (friend, parent, } \\
\text { senior, etc) }\end{array}$ & $38,2 \%$ & LOW \\
\hline 6. Open the dictionary & $64,5 \%$ & LOW \\
\hline 7. Do Excercises & $74,5 \%$ & HIGH \\
\hline 8. Practice grammar, vocabulary, dan pronunciation & $67,3 \%$ & HIGH \\
\hline
\end{tabular}


The Problems in Associating Stage

According to Kemendiknud 2016

in Sufairoh (2016), associating train students to develop an attitude of honesty, conscience, discipline, obedience to rules, hardwork, ability to apply procedures and the ability to think inductively and deductively in conclude the material being studied. In this stage the lowest percentages is arrange answers for the formulated questions that is $49.1 \%$. To strengthen the data, researcher conducted an observation. Based on observations there are three activities not carried out by students and one of them is arrange answers for the formulated questions. From these two data we can see that students do not arrange answers for the formulated questions in questioning stage. It means that students not able to think inductively or deductively in conclude the material being studied.

Table 7. Observation sheet (Associating stage)

\begin{tabular}{lll}
\hline STATEMENT & YES & NO \\
\hline 1. Identifying pattern (grammar, vocabulary, or pronunciation) & V & \\
\hline 2. Formulating pattern (grammar, vocabulary, or pronunciation) & & V \\
\hline 3. Finding answers for the formulated questions & V \\
\hline 4. Drawing conclusion & V \\
\hline
\end{tabular}

Table 8. Questionnaire Percentages (Associating stage)

\begin{tabular}{llcc}
\hline STATEMENT & & PERCENTAGES & CATEGORIES \\
\hline $\begin{array}{l}\text { 1. Identifying pattern } \\
\text { pronunciation) }\end{array}$ & (grammar, vocabulary, or & $66,4 \%$ & HIGH \\
\hline $\begin{array}{l}\text { 2. Formulating pattern (grammar, vocabulary, or } \\
\text { pronunciation) }\end{array}$ & $57,3 \%$ & MEDIUM \\
\hline $\begin{array}{l}\text { 3. Arrange answers for the formulated questions } \\
\text { 4. Drawing conclusion }\end{array}$ & $39,1 \%$ & LOW \\
\hline
\end{tabular}

\section{The Problems in Communicating} Stage

In this stage, students communicate their answers or conclusions to the class in writing and/or orally. Their answers (conclusions) represent a new knowledge they have construct or learn. At the end of this stage, students are expected to have learned the necessary knowledge (especiallly about the social function of the text, structure of the text, grammar, and vocabulary) in order to comprehend and create texts. From the data, no problems was found. All items are in medium-high categories. But from all the items, continue a text or story that is being studied is one of items in medium category that is $53.6 \%$. But, in observation result, Students continue a text that is being studied. So, we can conclude that there is no problems in this stage.

Table 9. Observation sheet (Communicating stage)

\begin{tabular}{lll}
\hline STATEMENT & YES & NO \\
\hline 1. Presenting conclusions in written or oral form & V & \\
\hline 2. Presenting conclusions in front of the class & V & \\
\hline 3. Exchange the answers(conclusion) to the other friends or groups. & & V \\
\hline 4. Make a summary of the material that has been studied & & V \\
\hline 5. Continue a text or story that is being studied & V & \\
\hline
\end{tabular}


Table 10. Questionnaire Percentages (Communicating stage)

\begin{tabular}{lcc}
\hline \multicolumn{1}{c}{ STATEMENT } & PERCENTAGES & CATEGORIES \\
\hline 1. Presenting conclusions in written or oral form & $67,3 \%$ & HIGH \\
\hline 2. Presenting conclusions in front of the class & $67,3 \%$ & HIGH \\
\hline $\begin{array}{l}\text { 3. Exchange the answers (conclusion) to the other } \\
\text { friends or groups. }\end{array}$ & $65,5 \%$ & HIGH \\
\hline 4. Make a summary of the material that has been studied & $63,6 \%$ & HIGH \\
\hline 5. Continue a text or story that is being studied & $53,6 \%$ & MEDIUM \\
\hline
\end{tabular}

\section{B. Factors causing the Problems Factors causing the problems in Observing stage}

From the result of interview, it was found that there are four factors causing the problems in this stage. The result is presented below.

"Malas saya baca buku kak, ...."

(I'm lazy to read the book bro)

"saya gak tau apa yang di baca itu

kak, gak saya ngerti kalo baca sendiri"

(I do not know what I read, bro, and I do not understand if I read it)

"gak tertarik saya baca-baca itu kak, lebih baik saya denger orang jelasin." (I am not interested in reading, I better listen to people's explanations)

"Iya kak, soalnya temen saya ngajak saya ngobrol jadi kadang ga perhatiin guru jelasin"

(Yes bro, because my friend invited me to chat, so sometimes I do not listening to the teachers' explanation)

The data above show us that the problems come because of laziness, low of basic knowledge, students' interest, and because of their friends. Laziness is included in students' motivation. Based on Aunurrahman (2014), Motivation is strength that can be a driving force for students utilize the potentials that exist in themselves and potential outside themselves to realize learning goals. Basic knowledge and students' interest are included in characteristic of students. If they do not have basic knowledge, they will find it difficult to understand the material. When they are not interested in the material, they will not learn it seriously. The last factor causing the problem is their friend. from the results of interview above, students feel disturbed when their friends invite to talk. This will affect the concentration of students while they learn. So that, material being studied is not well received.

\section{Factors causing the problems in Questioning stage}

The result of interview proved that there are many factors causing the problems in this stage. The result is presented below.

"Gurunya juga kadang diem-diem aja kak, gaada nyuruh kita nanyak"

(Sometime the teacher kept quiet, she didn't ask us to ask)

"Percuma saya nanya, soalnya saya juga belum paham materinya. Jadi kalau saya nanya itu malah makin bingung"

(It's useless if I ask, because I don't understand the material. So if I ask, I will be even more confused)

"Jarang merhatiin guru saya kak, temen2 ngajak ngobro lajak, jadi gatau saya mau tanyain apa."

(I rarely pay attention to the teacher, because my friend invites me to chat, so I don't know what to ask)

"Gak pingin tau saya tentang itu kak, dia sama ajak menurut saya."

(I don't want to know about that bro, I think, it's same."

At this stage, the factors causing the problems are their basic knowledge, motivation, interest, and some external factors, such as: teacher and friends. Based on Aunurrahman (2014), basic knowledge and interest are included in students' characteristics. If they do not have basic knowledge, it is hard to understand the material. As well as students' interest, if they are not interested with the material, they will not be triggered to ask anything 
about the material. Students do not have motivation to ask the question, because they think it is not important to ask. When there is no motivation on their self it will prevent them to do something, especially to ask question about material.

Besides internal factors, there are two external factors causing the problems. The first is teacher, teacher should give students motivation to do something. But in fact, teacher do not do anything for triggers students to ask something that relates to material being studied. Second is friends, their friends sometimes bother and it make them not focus on teacher explanation, so that they do not know what they will ask in this step. Students feel lazy to ask, because situation in class are noisy.

\section{Factors causing the problems in Collecting Data stage}

There were only two problems found in this stage. These problems occur because of three factors. There are some result of interview that proved the factors:

"Gapernah, Malu mauwawancara sama guru.",

(Never, I'm ashamed to interview the teacher)

"yaa males aja untuk gitu"

(yaa, I'm lazy to do that)

"ya biasanya ngikut apa yang disuruh guru aja...."

(ya, i'm usually follow only what teacher ask...)

"Udah tau juga kak, jadi buat apa nanya ke orang lain."

(Already know bro. So why should I ask others?)

"Ngapain wawancara-wawancara lagi, orang sekarang gampang kita carik di internet."

(Why should I interviews again, now easy to find it in internet)

First factor is self-confidence. According to Aunurrahman (2014), confidence is one of the pshycological conditions of a person that affects physical and mental activity in learning process. In this step factor of self-confidence divided into two, that are lack of confidence and too confidence. While students have lack of confidence, they will not do interview with teacher or others, because they are afraid to make mistakes when they asking. Students do not want to interview teacher or others because they afraid to do something wrong. So that when students are too confidence, they will not do interview to get more information about material. They think that they can get it only from the internet, but without realizing it, when they open their gadget, they will play and no longer look for information related to material being studied. The second factor is laziness. Laziness is included in motivation; it means that students feel lazy because they do not have motivation to do that. So it is clear that students must have high motivation to do something, especially related to find more information through interviews.

\section{Factors causing the problems in Associating stage}

In this stage, only one problem was found but that is arises from many factors. First factor is motivation, where it is divided into two factor, that are ignorance and laziness. Both of these factors emerge from Students' psychology. Ignorance and laziness make them not do anything. While at this stage they must arrange answers for formulating question. Social environment is second factor causing the problem. As a social being, students cannot break free from interaction with the environment, especially peers at school (Aunurrahman, 2014). Teacher and friends are two factors that are included in social environment. Both of these factors are very important to support students to achieve learning objectives. But in fact, teacher do not support students to do the activity. Teacher seldom ask and help students for arrange answers for formulating question, it makes students not do the activity and results of observing, questioning, and collecting data 
seen useless. Besides teacher, friends also take crucial part to arrange the answers. Students get motivation when their friends do the activity, but most of them so not do that. So the others students think that arranging the answers are not important. All of these factors proved by result of interview. The result of interview presented below.

"Males saya, apa yang mau disusun cobak? Dia sama ajak"

(I'm lazy, what would be arranged? It same)

"Gurunya gapernah nyuruh, jadi kita tulis2 biasa aja apa yang penting. Temen2 juga gaada yang gitu" (teacher never ask, so we wrote the important things. My friends also not do that)

"Gaperlu nyusun2 gituan kak, catet aja udah cukup. Gurunya juga gapernah liat catetan"

(not important arranged such things bro, note is enough. Also teacher never seen our note)

\section{Factors causing the problems in Communicating stage}

At this stage, only a few students encountered the problems. But in general, there is no problem found. The students who face problems in this stage was caused by laziness, motivation, ignorance, and friends who were not supportive. All of these factors not too affect activities in this stage. So we can conclude that in this stage, students do not have problems and factors causing the problems can controlled by themselves.

\section{Problems Solving}

According to Aunurrahman (2014) motivation in learning activities is a strength that can be a driving force for students utilize the potentials that exist in themselves and potential outside themselves to realize learning goals. So, to increase Students' motivation, teacher can use diverse methods and activities, create challenging task but realistic and appropriate, and give instructions to students to be successful in learning. To make students confidence with their self, teacher should create activities that involve all students in the class, care about the students, increase the competitive spirit of students, give appreciation, and encouraging them to follow the activities with his friends. Besides that, to solve the problems that are caused by characteristics of students, teacher get to know the interest and abilities of students.

To solve problems that are caused by external factors, teacher can make rules in the class, so that class situation can be managed. Do not give students too much use their gadget, always pay attention to students, and give punishment when students break the rules.

\section{CONCLUSION AND SUGGESTION}

\section{A. Conclusion}

There are some problems encountered by English students in learning English using scientific approach. Problems in observing stage are related to reading the text or materials being studied. Problems in questioning stage are mostly the problems in asking about social function, structure, and linguistics elements of the text. Problems in collecting data stage are interviews teacher or other besides teacher (friend, parent, senior, etc). Problems in associating stage is arrange answers for the formulated questions. There is no problems in communicating stage. The other result shows that there are 5 factors that cause the problems. The factors causing the problems are students' motivation, characteristics, self-confidence, and teacher and friends.

\section{B. Suggestion}

The students should enrich their experiences in learning English. They also need to increase their motivation and interest to learn English well. For the teachers, it is suggested, that they have to consider a better way in teaching English 
in order to improve the students' motivation in learning English. In addition, there are still many aspects which can be analyzed about scientific approach that use in Curriculum 2013 and other approach. Finally, other researchers have to do further research with other aspects in scientific approach and other approaches in learning English and the result of this study may be used as early information to conduct further research.

\section{REFERENCES}

Abidin, Y. (2014). Desain System Pembelajaran Dalam Konteks Kurikulum 2013. Bandung: PT Refika Aditama

Atsnan, M.F. and Gazali Y.R. (2013). Penerapan Pendekatan Saintifik dalam Pembelajaran Matematika. A Discussion Paper, ISBN: 97897916353-9-4.

Aunurrahman. (2014). Belajar dan Pembelajaran. Bandung: Alfabeta

Daryanto. (2014). Pendekatan Pembelajaran Saintifik Kurikulum 2013. Yogyakarta: Gava Media.
Kemdikbud. 2013. Permendikbud $81 a$ tahun 2013 Tentang Standar Proses Pendidikan dasar dan Menegah. Jakarta: Kementrian Pendidikan dan Kebudayaan.

Ruhimat, T. (2011). Kurikulum dan Pembelajaran. Jakarta: Rajawali Press.

Sarwanti, S. (2016). Scientific Method in English Language Teaching. https://jurnal/untidar.ac.id/index.ph p/transformatika/article/view/200. Retrieved on Monday, October 7 2019

Sufairoh. (2016). PENDEKATAN SAINTIFIK \& MODEL PEMBELAJARAN K-13. http://www.jurnalpendidikanprofes ional.com/index.php/jpp/article/vie w/186. Retrieved on Tuesday, October 82019

Trisagita, O. (2018). Teachers' Difficulties in Teaching English Using Scientific Approach: A Study at Public Senior High Schools in Mataram 